JOSM

32,6

92

Received 14 December 2020

Revised 28 June 2021

3 September 2021

Accepted 9 September 2021

\section{How industry and occupational stereotypes shape consumers' trust, value and loyalty judgments concerning service brands}

\author{
Petar Gidaković \\ Research Centre, School of Economics and Business, University of Ljubljana, \\ Ljubljana, Slovenia, and \\ Vesna Zabkar \\ School of Economics and Business, University of Ljubljana, Ljubljana, Slovenia
}

\begin{abstract}
Purpose - Longitudinal studies have shown that consumer satisfaction has increased over the last 15 years, whereas trust and loyalty have decreased during the same period. This finding contradicts the trust-valueloyalty model (TVLM), which posits that higher satisfaction increases consumers' trust, value and loyalty levels. To explain this counterintuitive trend, this study draws on models of trust formation to integrate the stereotype content model and the TVLM. It argues that consumers' occupational and industry stereotypes influence their trust, value and loyalty judgments through their trusting beliefs regarding frontline employees and management practices/policies.

Design/methodology/approach - The study was conducted among 476 consumers who were randomly assigned to one of five service industries (apparel retail, airlines, hotels, health insurance or telecommunications services) and asked to rate their current service provider from that industry.

Findings - The results suggest that both occupational and industry stereotypes influence consumers' trusting beliefs and trust judgments, although only the effects of industry stereotypes are transferred to consumers' loyalty judgments.

Research limitations/implications - The results of the study indicate that industry stereotypes have become increasingly negative over the last decades, which has a dampening effect on the positive effects of satisfaction.

Practical implications - This study provides guidelines for practitioners regarding the management of frontline employees and the development of consumer trust, value and loyalty.

Originality/value - This is the first study to propose and test an explanation for the counterintuitive trend concerning customer satisfaction, trust and loyalty. It is also the first to examine the roles of multiple stereotypes in the relationship between consumers and service providers.
\end{abstract}

Keywords Occupational stereotypes, Service industry stereotypes, Consumer trust, Consumer loyalty, Frontline employees, Service brands, Satisfaction

Paper type Research paper

\section{Introduction}

Due to its important contribution to firm performance, building customer loyalty represents one of the key strategic goals for marketers (Edeling and Fischer, 2016; Watson et al., 2015). The trust-value-loyalty model (TVLM), which was developed by Jagdip Singh and

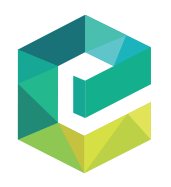

(C) Petar Gidaković and Vesna Zabkar. Published by Emerald Publishing Limited. This article is published under the Creative Commons Attribution (CC BY 4.0) licence. Anyone may reproduce, distribute, translate and create derivative works of this article (for both commercial and non-commercial purposes), subject to full attribution to the original publication and authors. The full terms of this licence may be seen at http://creativecommons.org/licences/by/4.0/legalcode.

Authors gratefully acknowledge financial support from Slovenian Research Agency (grants P5-0128 and N5-0084) and School of Economics and Business, University of Ljubljana.
Journal of Service Management Vol. 32 No. 6,2021 pp. $92-113$ Emerald Publishing Limited 1757-5818

DOI 10.1108/JOSM-12-2020-0447 
colleagues (Nijssen et al., 2003; Singh and Sirdeshmukh, 2000; Sirdeshmukh et al., 2002), is among the most widely adopted theoretical frameworks for explaining the development of consumer loyalty in service industries. Briefly put, the TVLM proposes that trust and value act as sequential mediators of the effects of satisfaction on loyalty. The key assumption is that consumers primarily rely on provider-specific information gathered over the course of service episodes to render and update their trust, value and loyalty judgments (Singh and Sirdeshmukh, 2000; Sirdeshmukh et al., 2002). This explains why satisfaction, which captures the valence of such service episodes, is the most commonly studied antecedent of the TVLM (e.g. Molinillo et al., 2017; Nijssen and Van Herk, 2009; Nijssen et al., 2003; Sirdeshmukh et al., 2002).

However, the longitudinal, multi-industry surveys that have tracked consumers' satisfaction, trust and loyalty levels over recent decades offer counterintuitive findings. While customer satisfaction has increased over the past 15 years (American Customer Satisfaction Index, 2019), consumers' trust (Edelman, 2020; Rajavi et al., 2019) and loyalty (Dawes et al., 2015; Evanschitzky et al., 2020) levels have decreased. These results raise questions about the predictive validity of the TVLM and indicate the need for investigations of the factors other than satisfaction that influence the development of consumers' trust, value, and loyalty judgments.

Theoretical models of trust formation suggest that categorization processes and the resultant stereotypes play an important role in trust development (Mcknight et al., 1998; Williams, 2001). Stereotyping is a common psychological mechanism that people rely on to simplify their cognition (Macrae et al., 1994). Research from the psychology and consumer behavior domains indicates that consumers' judgment is influenced by occupational stereotypes (e.g. Imhoff et al., 2018) and service industry stereotypes (e.g. Batra et al., 2010; Loken, 2006). Building on such research, we theorize that consumers rely on both stereotypes and satisfaction when forming their trusting beliefs. Moreover, we argue that consumers' industry stereotypes affect their trusting beliefs about management practices and policies, whereas occupational stereotypes drive their trusting beliefs about frontline employees. In turn, these trust dimensions (i.e. trusting beliefs) mediate the effects of stereotypes on consumers' trust, value and loyalty judgments.

To consistently capture the content of consumers' occupational and industry stereotypes, we draw on the stereotype content model (Fiske et al., 2002), which has previously been adopted to investigate other kinds of stereotypes that consumers hold with regard to service brands (e.g. global/local or for profit/non-profit stereotypes) and employees (e.g. race or gender stereotypes (Aaker et al., 2010; Madera et al., 2019; Smith et al., 2016)). The integration of the stereotype content model and the TVLM is considered a valid approach because the former suggests that stereotypical content can be captured alongside the dimensions of warmth and competence (Fiske et al., 2002), which correspond to the benevolence and competence trusting beliefs within the TVLM (Fournier and Alvarez, 2012; Sirdeshmukh et al., 2002). To test this extended conceptual model, we conducted a survey concerning brands from five service industries among 476 consumers from the United States (US). The results indicate the direct impact of both industry and occupational stereotypes on consumers' trusting beliefs regarding management practices and policies as well as frontline employees. However, only the indirect effects of industry stereotypes affect the entire TVLM chain. Finally, the results have important implications for service brand differentiation and the management of frontline employees.

\section{Conceptual background and hypotheses}

\section{Consumer relationships with service brands and the TVLM}

The development of consumer loyalty, which is defined as "a deeply held commitment to rebuy or repatronize a preferred product/service consistently in the future" (Oliver, 1999,
Consumers' trust, value and loyalty judgments 
JOSM 32,6

\section{4}

p. 34), represents a key strategic goal for most companies (Kumar, 2018) due to the beneficial effects of loyalty on firms' operational and financial market performance (Fornell et al., 2016; Petersen et al., 2018). Marketing scholars have accordingly proposed several models for explaining consumer loyalty development (Dick and Basu, 1994; Fornell et al., 1996; Oliver, 1999; Sirdeshmukh et al., 2002). In the present paper, we focus on the TVLM because it was constructed to explain loyalty development toward service brands and it has been tested in various settings (see Table 1).

Building on goal and action identification theories, the TVLM posits that consumers' perceptions of value, which is "defined as the perception of the benefits minus the costs of maintaining an ongoing relationship with a service provider," mediate the effects of satisfaction, trusting beliefs and trust on loyalty (Sirdeshmukh et al., 2002, p. 21). The rationale behind the mediating role of value is that trust reduces relational risk and other costs while simultaneously increasing relational benefits such as convenience, efficiency and enjoyment (Agustin and Singh, 2005; Chai et al., 2015; Singh and Sirdeshmukh, 2000). Early TVLM studies present mixed results, with some observing the complementary mediation of perceived value (Nijssen et al., 2003) and others finding more evidence of indirect-only mediation (Sirdeshmukh et al., 2002). More recent studies, however, provide clear evidence of indirect-only mediation (Chai et al., 2015; Molinillo et al., 2017; Nijssen and Van Herk, 2009). We follow this more recent stream of the TVLM literature and model perceived value as an indirect-only mediator (Zhao et al., 2010) of the effects of consumers' stereotypes, trusting beliefs and trust on loyalty.

Trust, which is defined as a "willingness to rely on an exchange partner in whom one has confidence," is the third cornerstone of the TVLM (Moorman et al., 1993, p. 82). A recent metaanalysis finds significant positive elasticity between consumer trust and loyalty (Khamitov et al., 2019), thereby reaffirming previous meta-analytical findings involving business-tobusiness) samples (Palmatier et al., 2006; Vieira, 2013). Trust is usually conceptualized as a multidimensional construct consisting of trusting beliefs and intentions (Mayer et al., 1995; Mcknight et al., 1998; Morgan and Hunt, 1994). The TVLM proposes that trusting beliefs consist of benevolence and competence dimensions. Within the service industries, consumers interact with frontline employees who are tasked with implementing management practices and policies. The TVLM accordingly predicts that consumers' trusting beliefs regarding both frontline employees and management practices and policies serve as the determinants of consumer trust (Sirdeshmukh et al., 2002).

The benevolence and competence dimensions of consumers' trusting beliefs regarding management practices and policies as well as frontline employees capture the four dimensions of consumer trust in (1) the motivation of a provider to put the interests of the consumer first and (2) the ability of a provider to consistently deliver the expected service (Sirdeshmukh et al., 2002). The TVLM further assumes that consumers form such beliefs as they interact with the provider and experience satisfaction (Singh and Sirdeshmukh, 2000; Sirdeshmukh et al., 2002). Nevertheless, longitudinal studies show that consumers' global service evaluations are not particularly sensitive to changes in the performance of providers across service episodes (Bolton and Drew, 1991a, b). These results imply that consumers rely on additional psychological mechanisms alongside experience-based confirmation of service expectations (i.e. satisfaction) when assessing trust, value, and loyalty.

Prior research on the TVLM model acknowledges that consumers might rely on other psychological constructs than satisfaction, for example, industry dispositions and culturally shared mental models (Nijssen et al., 2003; Singh et al., 2011). However, the literature lacks a comprehensive theoretical account that explains how such psychological mechanisms fit within the TVLM. Thus, we expand the TVLM by building on models of interpersonal trust development (Foddy et al., 2009; Mcknight et al., 1998; Williams, 2001), which predict that 


\begin{tabular}{|c|c|c|c|c|c|}
\hline Study & Study context & $\begin{array}{l}\text { Antecedents of } \\
\text { trust studied }\end{array}$ & $\begin{array}{l}\text { Trust } \\
\text { conceptualization }\end{array}$ & Main findings & $\begin{array}{l}\text { Consumers' } \\
\text { trust, value and }\end{array}$ \\
\hline \multirow[t]{2}{*}{$\begin{array}{l}\text { Singh and } \\
\text { Sirdeshmukh } \\
\text { (2000) }\end{array}$} & \multirow[t]{2}{*}{ Conceptual paper } & \multirow[t]{2}{*}{$\begin{array}{l}\text { Satisfaction, price } \\
\text { premiums, price } \\
\text { fairness }\end{array}$} & \multirow[t]{2}{*}{-} & \multirow{2}{*}{$\begin{array}{l}\text { The authors propose a } \\
\text { dynamic relationship } \\
\text { between trust and } \\
\text { satisfaction, where } \\
\text { consumers' encounter- } \\
\text { specific satisfaction } \\
\text { updates their trust beliefs } \\
\text { of benevolence and } \\
\text { competence in the service } \\
\text { brand }\end{array}$} & judgments \\
\hline & & & & & \\
\hline $\begin{array}{l}\text { Sirdeshmukh } \\
\text { et al. (2002) }\end{array}$ & $\begin{array}{l}\text { Airline, apparel } \\
\text { retailer }\end{array}$ & $\begin{array}{l}\text { Problem-solving } \\
\text { orientation, } \\
\text { operational } \\
\text { benevolence and } \\
\text { competence of } \\
\text { frontline employees, } \\
\text { and management } \\
\text { policies and } \\
\text { practices }\end{array}$ & Multidimensional & $\begin{array}{l}\text { The authors demonstrate } \\
\text { that trust and value } \\
\text { mediate the effects of } \\
\text { trusting perceptions and } \\
\text { show that negative } \\
\text { trusting perceptions } \\
\text { exhibit stronger effects } \\
\text { on trust than positive } \\
\text { ones }\end{array}$ & \\
\hline $\begin{array}{l}\text { Nijssen et al. } \\
(2003)\end{array}$ & $\begin{array}{l}\text { Airline, apparel } \\
\text { retailer }\end{array}$ & $\begin{array}{l}\text { Satisfaction and } \\
\text { consumer } \\
\text { dispositions toward } \\
\text { firms in terms of } \\
\text { valence and } \\
\text { marketplace } \\
\text { efficacy }\end{array}$ & Unidimensional & $\begin{array}{l}\text { The authors demonstrate } \\
\text { that both consumer } \\
\text { disposition and } \\
\text { satisfaction affect the } \\
\text { TVLM constructs and } \\
\text { find the moderating } \\
\text { effects of consumer } \\
\text { dispositions in the } \\
\text { trust-value chain }\end{array}$ & \\
\hline $\begin{array}{l}\text { Agustin and } \\
\text { Singh (2005) }\end{array}$ & $\begin{array}{l}\text { Airline, apparel } \\
\text { retailer }\end{array}$ & Satisfaction & Unidimensional & $\begin{array}{l}\text { The authors find that } \\
\text { trust and value partially } \\
\text { mediate the effects of } \\
\text { satisfaction on loyalty. } \\
\text { They also show that } \\
\text { satisfaction and value } \\
\text { have a decreasing rate } \\
\text { of return, while trust } \\
\text { exhibits an increasing } \\
\text { rate of return in terms of } \\
\text { predicting loyalty }\end{array}$ & \\
\hline $\begin{array}{l}\text { Nijssen and } \\
\text { Van Herk } \\
\text { (2009) }\end{array}$ & $\begin{array}{l}\text { Cross-national } \\
\text { relational } \\
\text { exchanges } \\
\text { (Dutch-German), } \\
\text { bank customers }\end{array}$ & Satisfaction & Unidimensional & $\begin{array}{l}\text { The authors find strong } \\
\text { support for the TVLM } \\
\text { model, but find no } \\
\text { moderating effects of tax } \\
\text { benefits or consumer } \\
\text { ethnocentrism. They find } \\
\text { only partial support for } \\
\text { the moderating effects of } \\
\text { consumer beliefs about a } \\
\text { foreign industry } \\
\text { (continued) }\end{array}$ & $\begin{array}{r}\text { Table } 1 . \\
\text { A summary of prior } \\
\text { studies investigating } \\
\text { the TVLM }\end{array}$ \\
\hline
\end{tabular}


JOSM

32,6

\begin{tabular}{|c|c|c|c|c|}
\hline Study & Study context & $\begin{array}{l}\text { Antecedents of } \\
\text { trust studied }\end{array}$ & $\begin{array}{l}\text { Trust } \\
\text { conceptualization }\end{array}$ & Main findings \\
\hline $\begin{array}{l}\text { Singh et al. } \\
\text { (2011) }\end{array}$ & $\begin{array}{l}\text { Insurance } \\
\text { industry in three } \\
\text { countries } \\
\text { (Germany, The } \\
\text { Netherlands, and } \\
\text { The US) }\end{array}$ & $\begin{array}{l}\text { Satisfaction, } \\
\text { CLIMA - shared } \\
\text { and socially } \\
\text { constructed mental } \\
\text { model for the social } \\
\text { structure of }\end{array}$ & Unidimensional & $\begin{array}{l}\text { The authors find that } \\
\text { CLIMA has direct effects } \\
\text { on trust, satisfaction, and } \\
\text { value; it also moderates } \\
\text { their effects on customer } \\
\text { loyalty }\end{array}$ \\
\hline
\end{tabular}

\section{6}

\section{Marinova and A zoological Singh (2014) society in the US}

marketplace exchanges Identity salience, perceived benefits, perceived costs

Banking industry

(2015) in New Zealand

El-Manstrly

(2016)

Molinillo et al. (2017)

This study
Online apparel retail in Spain

Hairdressers and fast-food restaurants in Scotland

Satisfaction, affective experiential state

Airline, apparel retail, insurance, hotel, and telecom in the US
Satisfaction, occupational and industry stereotypes

Table 1.

Unidimensional The authors find that neither trust nor value affect membership renewal decisions; only trust predicts a membership upgrade decision

Multidimensional The authors propose two-dimensional conceptualizations of trust (cognitive and emotional), perceived value (utilitarian ad hedonic), and loyalty (repurchase and advocacy intentions)

Unidimensional The author finds that only procedural and financial switching costs moderate the direct relationships of the TVLM, such that the effects of trust and value on loyalty become more important as the switching costs increase

Unidimensional The authors conclude that both satisfaction and affective experiential state positively affect trust, which further carries their effects to value and loyalty

Multidimensional We find that occupational stereotypes predict the trusting of frontline employees, while industry stereotypes predict the trusting of management policies and practices. However, only industry stereotypes exhibit a significant indirect effect on loyalty 
stereotypes determine trusting beliefs. For instance, Williams (2001) posits that categorybased beliefs (i.e. stereotypes) directly affect trusting beliefs and intentions toward an individual from that category. Similarly, McKnight et al. (1998, p. 481) argue that by "positive stereotyping, one can quickly form positive trusting beliefs about the other by generalizing from the favorable category into which the person was placed." We propose that consumers develop trusting beliefs by relying on stereotypes concerning a service industry and frontline employees' occupation.

\section{Consumers' stereotypes and their relationships with service brands}

Psychologists define stereotypes as "qualities perceived to be associated with particular groups or categories of people" (Schneider, 2005, p. 24). However, Aaker et al. (2010) demonstrate that consumers rely on similar categorization mechanisms with regard to service brands and also hold different stereotypes regarding for-profit and non-profit service companies. Thus, we adapt Schneider's (2005) definition and conceptualize stereotypes as qualities perceived to be associated with certain groups or categories of targets. This reconceptualization allows us to examine consumers' stereotypes about a given service industry (i.e. a group of companies or service brands that offer a similar service) as well as consumers' occupational stereotypes about frontline employees (i.e. a category of people).

Yet, while our conceptualization of stereotypes provides the foundation for theorizing in terms of their nomological relationships with consumers' trusting beliefs, it has nothing to say about the content of stereotypes (i.e. the qualities). To consistently capture the content of stereotypes, we rely on the stereotype content model (Fiske et al., 2002), which posits that people organize the substance of stereotypes on the basis of both warmth and competence. In this context, warmth captures the intentions of a group or category, and it is associated with qualities such as friendliness, honesty, likability and sincerity (Fiske, 2018). Moreover, competence captures the ability of a group or category to realize its intentions (Fiske et al., 2002). As a result, competence stereotypes are reflected in qualities such as skill, efficiency and intelligence (Fiske, 2018).

Marketing scholars have long acknowledged that consumers' beliefs and perceptions in relation to service companies might be stereotypical (Martineau, 1958; Tucker, 1961), although the theory that examines both the content and processes of consumer stereotyping is still emerging. In the following subsections, we review the literature concerning consumers' stereotypes about service industries and frontline employees. We focus on service industry stereotypes because the service industries represent categories of companies or service brands that provide a similar offering (Bajde, 2019; Nightingale, 1978), which renders them natural categories (Rosch, 1973). This means that the service industries are among the most commonly applied categories when it comes to stereotyping service companies or brands (Loken, 2006; Tucker, 1961). However, we do acknowledge that consumers may categorize and stereotype service companies or brands on the basis of additional categories, such as gender (Hess and Melnyk, 2016), for-profit/non-profit status (Aaker et al., 2010) or company size (Yang and Aggarwal, 2019).

Similarly, we focus on occupational stereotypes, although consumers may rely on other categories (e.g. age, ethnicity, gender and race) in addition to the occupation of frontline employees (Davies and Chun, 2012; Timming et al., 2020; Tombs and Rao Hill, 2014). However, it is important to recognize that the applicability of these stereotypes is contingent upon the characteristics of an individual frontline employee as well as dependent upon the situation. Moreover, any practical intervention concerning the management of frontline employees based on such categories may constitute a form of employee discrimination. Occupational stereotypes apply to whole groups of frontline employees within a given company (e.g. servers, clerks, salespeople, call center representatives). Further, recent

Consumers' trust, value and loyalty judgments 
JOSM 32,6

98

research from the field of psychology demonstrates that different occupations differ considerably in terms of the associated warmth and competence stereotypes (e.g. Imhoff et al., 2018). Occupations are, therefore, relevant social categories upon which people base their assessment of frontline employees (Gunia and Levine, 2019; Pinar et al., 2017), and they can also serve as managerially actionable categories of frontline employees.

Consumers' reliance on service industry stereotypes. Prior studies seem reluctant to invoke the construct of consumers' service industry stereotypes, which we define as consumers' warmth and competence beliefs regarding a service industry, and so offer alternative conceptualizations. For example, Nijssen et al. (2003, p. 48) propose the construct of consumer dispositions, which they define "as attitudes and action tendencies to respond to industrycontext situations in a particular, predetermined manner." Furthermore, they conceptualize dispositions as a two-dimensional construct consisting of valence and marketplace efficacy, which seem to reflect warmth and competence stereotypes. Nijssen et al. (2003) find that valence (but not marketplace efficacy) dispositions affect consumers' satisfaction and value judgments, but not their trust and loyalty judgments.

Similarly, Iglesias (2004, p. 91) proposes the construct of service category preconceptions, which he defines as "customer beliefs about the service category prior to the service encounter that is the object of study." Based on his operationalization of the construct, it appears to somewhat overlap with warmth stereotypes. Iglesias (2004) concludes that preconceptions positively affect consumers' evaluations of service quality dimensions, although only the reliability and empathy dimensions of service quality transfer their effects to consumers' overall service evaluation. Thus, both studies emphasize the role of perceived intentions (i.e. warmth stereotypes) and fail to provide support for the role of service industry competence stereotypes.

A number of recent studies rely on the stereotype content model to examine the impacts of warmth and competence stereotypes on consumers' relationships with service brands. For example, Valta's (2013) sample includes service brands and she finds that only competence (not warmth) stereotypes influence the quality of relationships. Japutra et al. (2018) demonstrate that both warmth and competence affect students' trust in a university; however, they conceptualize the direct effects of stereotypes on trust judgments and disregard the roles of trusting beliefs as mediators (Sirdeshmukh et al., 2002). Drawing on trust formation models (Mcknight et al., 1998; Williams, 2001), we propose a refined relationship between service industry stereotypes and trust, which is mediated by consumers' trusting beliefs concerning the management practices and policies of service companies. We expect that if consumers perceive a given service industry to be well intentioned, they are likely to believe that the management practices and policies of a service company or brand from that industry are benevolent. Similarly, the more that consumers perceive a service industry to be capable of enacting its intentions, the more positive their beliefs about the competence of an individual service company or brand from that industry are. Therefore, we offer the following hypotheses:

H1a. Consumers' industry warmth stereotypes are positively related to their trusting beliefs about the benevolence of a service company's management practices and policies.

$H 1 b$. Consumers' industry competence stereotypes are positively related to their trusting beliefs about the competence of a service company's management practices and policies.

Consumers' reliance on occupational stereotypes. Prior studies on consumer stereotyping document how the use of occupational stereotypes, which are defined as beliefs about the warmth and competence of occupational groups, affect consumers' evaluations of both 
frontline employees and the company. For example, Matta and Folkes (2005) manipulate frontline employees' gender to show that counter-stereotypical (versus stereotypical) genderoccupation matches result in more positive evaluations of a company. This effect is especially prevalent when consumers have little information about the service offered (Folkes and Patrick, 2003). In parallel, Mikolon et al. (2016) demonstrate that consumers' negative stereotypes regarding frontline employees negatively affect their perceptions of the interaction quality.

Studies that rely on the stereotype content model to examine occupational stereotypes also offer relevant insights. First, people associate different levels of warmth and competence with certain occupations (He et al., 2019; Imhoff et al., 2018). For example, doctors are stereotyped as more competent than nurses (Imhoff et al., 2018) and bank tellers are stereotyped as warmer than customer service representatives (He et al., 2019). Second, there is some evidence that consumers rely on occupational stereotypes to infer the warmth and competence of frontline employees. For instance, Hareli et al. (2013) demonstrate that people perceive doctors (versus no occupation) as warmer and more competent, while Huetten et al. (2019) show that patients' occupational stereotypes affect their satisfaction with physicians.

Finally, other research findings suggest that consumers' warmth and competence perceptions, which are derived from other stereotypes such as ethnicity (Gill, 2017), gender (Wu et al., 2016) or weight (Smith et al., 2016), influence their assessment of frontline employees. Such studies, together with models of trust formation (Mcknight et al., 1998; Williams, 2001), provide preliminary empirical and conceptual support for our predictions that consumers' perception of frontline employees' occupational group as being wellintentioned leads to the assumption that frontline employees are willing to put consumers' interests first. Following the same logic, consumers' perception of the ability of frontline employees' occupational group to enforce its intentions should lead consumers to believe that frontline employees are competent in relation to their tasks. Thus, we hypothesize the following:

H2a. Consumers' occupational warmth stereotypes are positively related to their trusting beliefs about the benevolence of a service company's frontline employees.

$H 2 b$. Consumers' occupational competence stereotypes are positively related to their trusting beliefs about the competence of a service company's frontline employees.

As the TVLM has already been well established (see Table 1), we do not hypothesize any additional direct effects. Rather, we treat the original TVLM relationships as a conceptual replication (Lynch et al., 2015). Our conceptualization, measures, and formal specification of the TVLM constructs and relationships follow those of previous studies (Nijssen and Van Herk, 2009; Nijssen et al., 2003; Sirdeshmukh et al., 2002). However, we are interested in the mediating roles of trusting beliefs, trust and value in terms of transferring the effects of stereotypes to loyalty. Studying this chain of effects can provide insights into the counterintuitive trend concerning customers' satisfaction, trust, and loyalty levels. Since the stereotypes offer information that is only relevant to the formation of consumers' trusting beliefs (Mcknight et al., 1998; Williams, 2001), we argue for indirect-only mediation (Zhao et al., 2010), meaning that both industry and occupational stereotypes exhibit only indirect effects on loyalty. Thus, we offer the following hypothesis:

H3. Consumers' trusting beliefs about (a) management practices and policies and (b) frontline employees, along with trust and value, mediate the effects of consumers' (a) industry and (b) occupational stereotypes on loyalty.

Finally, as we intend to increase the generalizability of our findings by testing the conceptual model in multiple service industries, we control for any potential heterogeneity due to
Consumers' trust, value and loyalty judgments 
JOSM 32,6

differences between the various industries with service category involvement as a covariate (Brocato et al., 2015). We also account for the effects of encounter-specific customer satisfaction as the most commonly studied antecedent of the TVLM chain (see Table 1). Figure 1 summarizes our conceptual model.

\section{Empirical study \\ Design, participants and measures}

Cross-sectional surveys are commonly used in studies of both the TVLM(see Table 1) and the stereotype content model (Cuddy et al., 2007; Ivens et al., 2015). Therefore, we relied on Prolific Academic, a crowdsourcing platform that requires participants to provide high-quality data (Peer et al., 2017), and recruited 543 respondents from the US Each respondent received compensation equivalent to $\$ 11.85$ per hour. For data quality assurance purposes, we included a directed query attention check (i.e. "Please, place this slider in the middle"; for further detail, see Abbey and Meloy (2017)), which allowed us to exclude 45 inattentive respondents. We also excluded 22 respondents who completed the survey in less than three minutes (Alexandrov et al., 2013). This resulted in a final sample of 476 respondents $(52 \%$ female, $M_{\text {age }}=34.48, \mathrm{SD}_{\text {age }}=12.84$ years, minimum $=18$ years, maximum $=72$ years).

After consenting to participate in the study, the respondents were randomly assigned to one of five groups $\left(n_{\text {apparel retail }}=93, n_{\text {airlines }}=95, n_{\text {hotels }}=91, n_{\text {health insurance }}=99\right.$, or $n_{\text {telecommunications services }}=98$ ) and asked to name their current provider in that industry or the provider they had most recently dealt with. Subsequently, all the constructs were measured on established scales related to the named service provider. This research design offered two main advantages over the use of a fictitious brand or a survey of customers of a single provider. First, the respondents had actual experience with the service company or brand, which prevented construct creation from the research questions, which occurs when fictitious brands are used as stimuli (for more details, see Forbes and Avis (2020)). Second, the research design enabled us to test the model across multiple service brands within each industry and

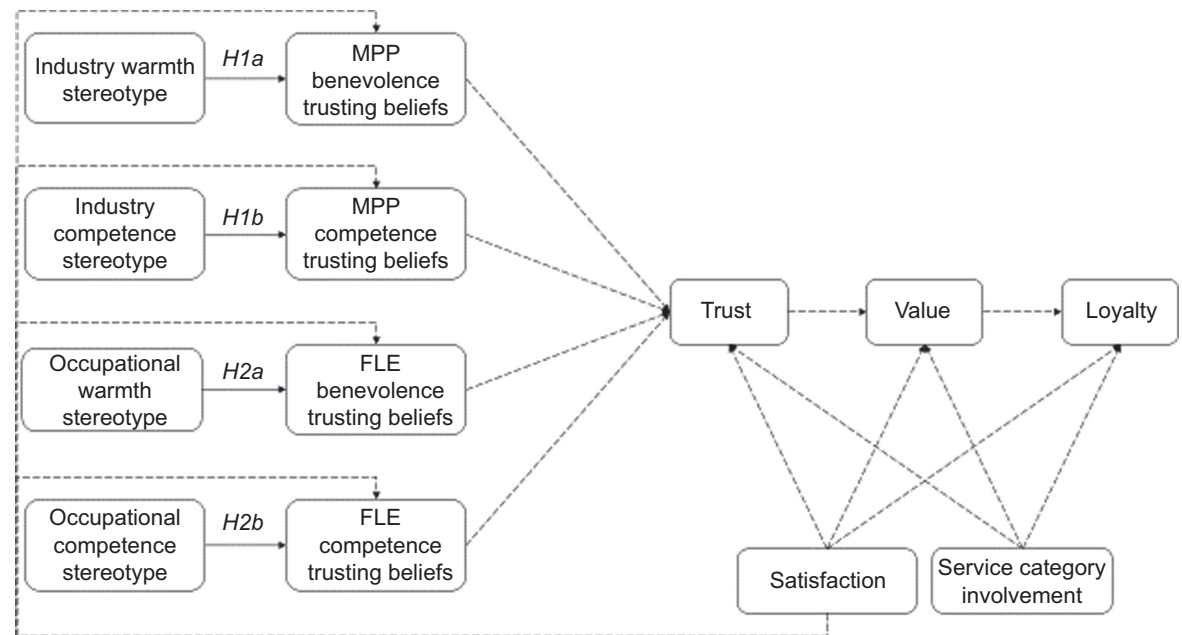

Figure 1.

The conceptual model
Note(s): MPP-management practices and policies; FLE-frontline employees. Solid lines represent hypothesized relationships, while dashed lines represent previously established relationships of the trust-value-loyalty model 
to control for any brand-specific findings. The most frequently named service brands were Target, H\&M, and Kohl's for the apparel retail industry; American Airlines, Southwest, and Delta for the airline industry; Hilton, Marriot, and Holiday Inn for the hotel industry; Blue Cross, Humana, and UnitedHealthcare for the insurance industry; and Verizon, AT\&T, and Comcast for the telecommunication service industry. We selected these five industries because they represent common research contexts within the literature on the TVLM (see Table 1).

To reduce the potential for common method bias, we ensured the anonymity of the respondents, relied on established measurement scales, made an effort to keep the measurement of the dependent and independent variables as distant as possible, and used various rating scale formats for the different constructs (Podsakoff et al., 2012). To measure loyalty $(1=$ Strongly disagree, $7=$ Strongly agree), we used three items from Rosengren and Dahlén (2015). For value $(1=$ Strongly disagree, $7=$ Strongly agree), we adopted four items from Karpen et al. (2015). For trust $(1=$ Strongly disagree, $5=$ Strongly agree), we used three items from Li et al. (2008). For benevolence and competence trusting beliefs concerning frontline employees as well as management practices and policies $(1=$ Strongly disagree, $5=$ Strongly agree), we adapted three items for each dimension from Sirdeshmukh et al. (2002). For warmth and competence occupational stereotypes (1-7 semantic differential), we used four items for each dimension from Kirmani et al. (2017). For warmth and competence industry stereotypes $(1=$ Not at all, $5=$ Extremely), we adopted four items per dimension from Halkias et al. (2016). To measure the control variables, we used three items (1-10 semantic differential) for encounter-specific satisfaction (Sirdeshmukh et al., 2002) and three items $(1=$ Strongly disagree, $7=$ Strongly agree) for category involvement (Brocato et al., 2015). All the scales' items, their loadings, and their reliabilities are presented in Table 2 . The significant and high standardized factor loadings and acceptable Cronbach's alphas provide initial evidence of the convergent validity and reliability of our measures (Bagozzi and Yi, 2012).

\section{Results}

Measurement model. Due to the cross-sectional nature of our data, we tested for the potential effects of common method bias using the marker variable technique (Bagozzi, 2011). Agreement with the statement "When I see a full ashtray or waste basket, I want it emptied immediately" was selected as the marker variable, since it is theoretically unrelated to the constructs in our conceptual model. The inclusion of the marker variable did not affect the fit of the measurement model or the factor loadings of the indicators on their substantive latent variables. Moreover, seven of the 13 correlations between the marker variable and the study constructs were not statistically significant, while the significant coefficients were small in magnitude $(r<0.18)$. This led us to conclude that common method bias was not likely to influence our findings.

Thus, we proceeded with the estimation of the measurement model, which fitted the data well $\chi^{2}=1,700.237$; degrees of freedom [df $]=867$ comparative fit index [CFI $]=0.959$; Tucker-Lewis index [TLI] $=0.954$; root mean square error of approximation $[$ RMSEA $]=0.045$; standardized root mean squared residual $[\mathrm{SRMR}]=0.044)$. The inspection of the composite reliabilities and average variances extracted (AVEs), as reported in Table 3, provided further evidence of reliability and convergent validity (Bagozzi and Yi, 2012). Moreover, the comparisons of the square roots of the AVEs and inter-construct correlations (see Table 3) supported the discriminant validity of our measures (Voorhees et al., 2016).

Structural model. We fitted the structural model from Figure 1 and obtained an acceptable fit $\left(\chi^{2}=2036.521 ; \mathrm{df}=910 ; \mathrm{CFI}=0.945 ; \mathrm{TLI}=0.940 ; \mathrm{RMSEA}=0.051 ; \mathrm{SRMR}=0.068\right)$.
Consumers' trust, value and loyalty judgments 
Loyalty (Cronbach's $\alpha=0.85)$

loadings

I am committed to BRAND

0.781

I would be willing to pay a higher price for BRAND than for other brands $\quad 0.644$

I will buy/use BRAND the next time I need SERVICE INDUSRTY

0.855

I intend to keep using BRAND

0.801

Value $(\alpha=0.92)$

BRAND offers good value for the price I pay

BRAND offers good value for the effort I make

0.929

BRAND offers good value for the time I invest

0.936

BRAND offers experiences that make me feel good

0.723

Trust (Cronbach's $\alpha=0.97$ )

I have no doubt BRAND can be trusted $\quad 0.903$

BRAND is trustworthy $\quad 0.979$

$\begin{array}{ll}\text { I Trust BRAND } & 0.954\end{array}$

Management practices and policies - benevolence trusting beliefs (Cronbach's $\alpha=0.90$ )

BRAND has practices that indicate respect for the customer $\quad 0.87$

BRAND favors the customer's best interests $\quad 0.92$

BRAND acts as if the customer is always right $\quad 0.818$

Management practices and policies - competence trusting beliefs (Cronbach's $\alpha=0.90$ )

BRAND has efficient customer service procedures

BRAND keeps its premises clean and free of clutter

BRAND is organized to keep things moving so you do not have to wait

0.734

Frontline employees - benevolence trusting beliefs (Cronbach's $\alpha=0.87$ )

The BRAND's employees act as if they value you as a customer 0.837

The BRAND's employees can be relied upon to provide accurate information 0.829

The BRAND's employees treat you with respect

0.883

Frontline employees - competence trusting beliefs (Cronbach's $\alpha=0.91$ )

The BRAND's employees work quickly and efficiently

The BRAND's employees can competently handle most customer requests $\quad 0.909$

The BRAND's employees can be relied upon to know what they are doing 0.912

Industry stereotypes - warmth (Cronbach's $\alpha=0.94$ )

Most people in the US see the companies from SERVICE INDUSTRY as friendly 0.892

Most people in the US see the companies from SERVICE INDUSTRY as good- 0.869

natured

Most people in the US see the companies from SERVICE INDUSTRY as kind

Most people in the US see the companies from SERVICE INDUSTRY as warm

Industry stereotypes - competence (Cronbach's $\alpha=0.90$ )

Most people in the US see the companies from SERVICE INDUSTRY as capable $\quad 0.897$

Most people in the US see the companies from SERVICE INDUSTRY as 0.901

competent

Most people in the US see the companies from SERVICE INDUSTRY as efficient 0.753

Most people in the US see the companies from SERVICE INDUSTRY as 0.755 intelligent

Occupational stereotypes - warmth (Cronbach's $\alpha=0.96$ ) Most people in the US view employees in the SERVICE INDUSTRY (e.g. claims examiners) as ...

Unfriendly/friendly 
Scale (Cronbach's alpha)/items

Unsociable/sociable

Not nice/nice
Standardized factor loadings

0.873

0.939
Consumers' trust, value and loyalty judgments

Occupational stereotypes - competence (Cronbach's $\alpha=0.94$ ) Most people in the US view employees in the SERVICE INDUSTRY (e.g. claims examiners) as ...

Incompetent/competent

.889

0.828

Not clever/clever

0.931

Not knowledgeable/knowledgeable

0.853

Service category involvement (Cronbach's $\alpha=0.94$ )

In general, I have a strong interest in SERVICE INDUSTRY. $\quad 0.944$

SERVICE INDUSTRY is very important to me $\quad 0.882$

SERVICE INDUSTRY means a lot to me

0.933

Satisfaction (Cronbach's $\alpha=0.95$ ) how would you describe your last encounter with BRANND ...

$\begin{array}{ll}\text { Highly unsatisfactory/highly satisfactory } & 0.921\end{array}$

$\begin{array}{lr}\text { Very unpleasant/very pleasant } & 0.949\end{array}$

Terrible/delightful

0.894

Table 2 .

Demonstrating strong direct effects, the model accounted for substantial variance of all the endogenous variables $\left(R^{2}\right.$ MPPbenevolence $=42.1 \% ; R_{\text {MPPcompetence }}^{2}=43.0 \%$; $R_{\text {FLE benevolence }}^{2}=35.6 \% ; R_{\text {FLEcompetence }}^{2}=36.1 \% ; R_{\text {Trust }}^{2}=57.2 \% ; R_{\text {Value }}^{2}=58.1 \%$; $R_{\text {Loyalty }}^{2}=49.0 \%$ ). Moreover, the estimates of the path coefficients (Figure 2) fully replicated the results of the core TVLM relationships (Nijssen and Van Herk, 2009; Nijssen et al., 2003; Sirdeshmukh et al., 2002). Customer satisfaction exhibited significant positive effects across all the dependent variables, which is consistent with the findings of previous studies (Molinillo et al., 2017; Nijssen and Van Herk, 2009; Nijssen et al., 2003; Singh et al., 2011; Sirdeshmukh et al., 2002). As expected, service category involvement significantly and positively affected trust, value, and loyalty (Brocato et al., 2015).

Importantly, the results of the structural model provide support for our first four hypotheses. Consistent with $\mathrm{H1a}$ and H1b, the effects of both industry warmth $(\gamma=0.238$; $p<0.001)$ and competence $(\gamma=0.161 ; p<0.001)$ stereotypes on consumers' trusting beliefs regarding the benevolence and competence of management practices and policies were significant and positive. Supporting H2a and H2b, both occupational warmth $(\gamma=0.111$; $p<0.01)$ and competence $(\gamma=0.193 ; p<0.001)$ stereotypes had a significant positive effect on consumers' benevolence and competence trusting beliefs regarding frontline employees.

To test the final two hypotheses, we followed the methodological literature on mediation analysis (Hayes et al., 2017; Iacobucci et al., 2007). More specifically, we fitted the proposed structural model (as depicted in Figures 1 and 2) and then bootstrapped 5,000 samples to construct $95 \%$ confidence intervals for the indirect effects of service industry warmth and competence stereotypes as well as occupational warmth and competence stereotypes on loyalty. Lending support to $\mathrm{H} 3 \mathrm{a}$, both the indirect effects of industry competence stereotypes $\left(\beta_{\text {indirect effect }}=0.003 ; \mathrm{CI}[0.001 ; 0.010] ; p=0.087\right)$ and the indirect effects of industry warmth stereotypes $\left(\beta_{\text {indirect effect }}=0.014\right.$; CI $\left.[0.007 ; 0.026] ; p<0.001\right)$ on loyalty were significant. However, the confidence intervals for the indirect effects of occupational competence stereotypes $\left(\beta_{\text {indirect effect }}=0.001 ; \mathrm{CI}[0.000,0.005] ; p=0.109\right)$ and occupational warmth stereotypes $\left(\beta_{\text {indirect effect }}=0.002 ; \mathrm{CI}[0.000,0.004] ; p=0.110\right)$ on loyalty contained a zero, leading us to reject H3b. To further determine the type of mediation, we followed the decision 


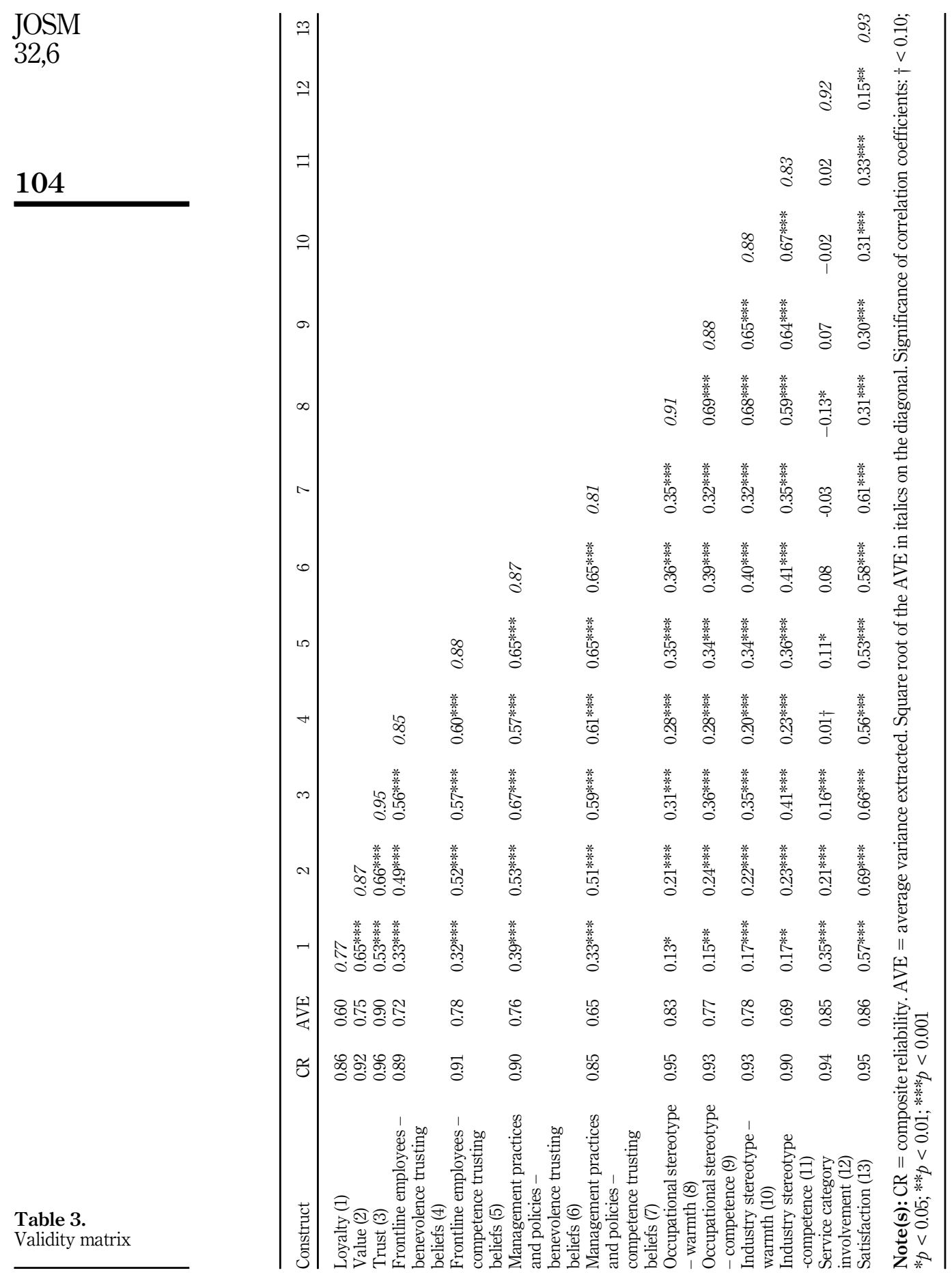




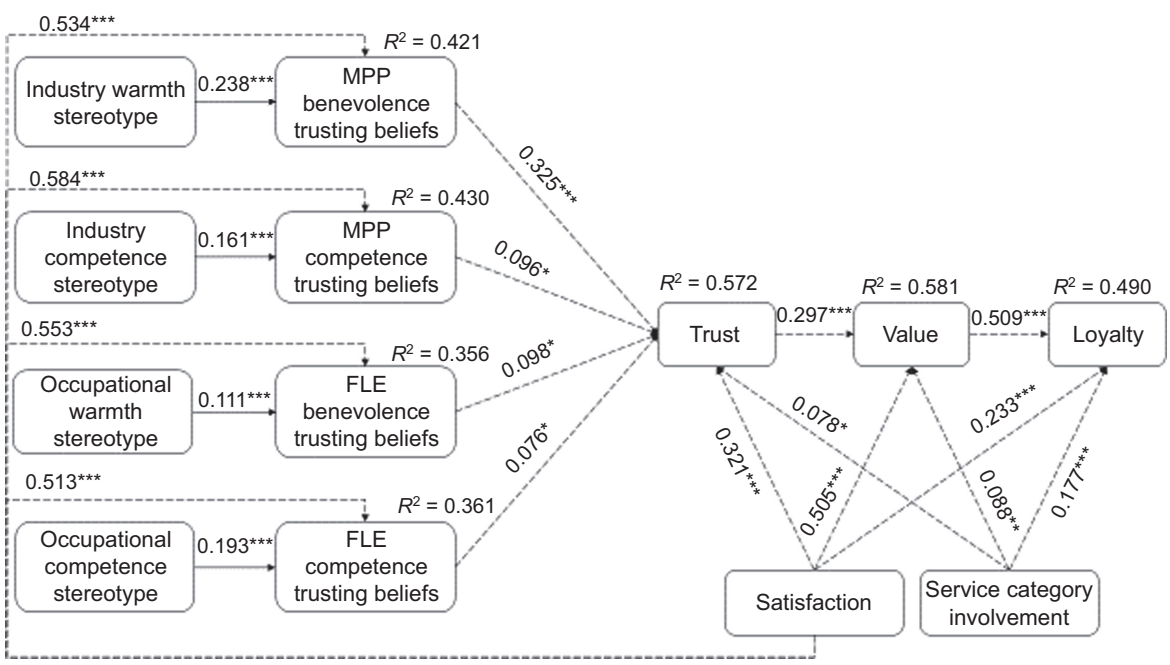

Note(s): MPP-management practices and policies; FLE-frontline employees. Solid lines represent hypothesized relationships, while dashed lines represent previously established relationships of the trust-value-loyalty model. Significance of standardized path coefficients: ${ }^{*} p<0.05 ; * * p<0.01$; $* * * p<0.001$

tree proposed by Zhao et al. (2010). An estimation of the structural model with direct paths from the four stereotype variables to loyalty freely estimated, did not lead to a significant improvement in the model fit $\left(\Delta \chi_{\mathrm{df}=4}^{2}=2.412\right)$, while all four paths turned out to be nonsignificant (all $p \mathrm{~s}>0.27$ ). This finding supports our expectation of indirect-only mediation by trusting beliefs, trust, and value in terms of transferring the effects of stereotypes to loyalty (Zhao et al., 2010).

\section{Discussion}

Research within the relationship marketing domain that examines the development of consumer loyalty to service brands largely neglects the heuristics that consumers rely upon to simplify their judgments (El-Manstrly, 2016; Molinillo et al., 2017). This paper sought to examine the roles of industry and occupational stereotypes in the formation of relationships between consumers and service brands. To accomplish this, we integrated two established theoretical models: the TVLM, which explains the evolution of consumer loyalty (Sirdeshmukh et al., 2002), and the stereotype content model, which takes into account the content of consumer stereotypes (Fiske et al., 2002). This enabled us to provide new insights into the development of consumer trust in service brands.

We also considered the mediating roles of consumers' trusting beliefs, trust, and value in terms of transmitting the effects of their industry and occupational stereotypes to loyalty. We followed the more recent stream of TVLM literature and modeled perceived value as an indirect-only mediator (Zhao et al., 2010) of the effects of stereotypes, trusting beliefs, and trust on loyalty. The results indicate that only industry stereotypes translate into loyalty, while the effects of occupational stereotypes stop at trust. Consumers rely on both the perceived qualities of a particular industry and the occupation of frontline employees when establishing trust in a service provider. However, in terms of loyalty to a service brand, industry stereotypes matter more than the qualities associated with a particular occupation of frontline employees.

\section{Consumers' trust, value and loyalty judgments}

105

Figure 2.

Structural model estimation results 
JOSM 32,6

106

\section{Theoretical implications}

According to the TVLM, higher satisfaction should lead to higher levels of trust and loyalty. Yet, longitudinal studies conducted in the service industries reveal a counterintuitive trend: consumer satisfaction has increased over recent decades, while trust and loyalty have decreased during the same period (ACSI, 2019; Evanschitzky et al., 2020; Rajavi et al., 2019). To explain this trend, we integrated the TVLM with the stereotype content model and found that consumers' industry stereotypes influence their trust, value and loyalty judgments through their trusting beliefs in management practices and policies. Our results imply that consumers' stereotypes regarding the warmth and competence of many service industries have become negative over the past 15 years, which could explain why increases in customer satisfaction have not translated into higher levels of trust and loyalty. However, our crosssectional analysis provides only initial insights, which should be corroborated with experimental and longitudinal evidence (Bagozzi and Yi, 2012).

This study contributes to two streams of marketing literature, namely relationship marketing and consumer stereotyping. While prior studies have proposed idiosyncratic constructs (Iglesias, 2004; Nijssen et al., 2003) to capture the heuristics upon which consumers base their trust, value, and loyalty judgments, we developed a more parsimonious conceptualization, which builds on the extensive psychological research on stereotypes. Through drawing on models of trust formation (Williams, 2001; Mcknight et al., 1998) we explicated the role of different types of stereotypes in shaping consumers' trust, value and loyalty judgments. More specifically, this study is the first to demonstrate that the development of consumers' trusting beliefs and intentions not only depends on their satisfaction with a service provider, as suggested by previous studies on the TVLM (Nijssen and Van Herk, 2009; Nijssen et al., 2003; Sirdeshmukh et al., 2002), but also on their warmth and competence stereotypes regarding the service industries and occupational groups of frontline employees. Our paper, therefore, provides a conceptual contribution in terms of the integration (Macinnis, 2011) of two previously unrelated research streams: the TVLM (see Table 1) and consumer stereotyping (Aaker et al., 2010; Kolbl et al., 2019; Smith et al., 2016).

We also provide new insights into trust formation. That is, we extended the models of trust formation that were developed in interpersonal settings (Mcknight et al., 1998; Williams, 2001) to the consumer-brand context. Our results show that the effects of stereotypes persist in the later stages of a relationship, which sheds some doubt on the theoretical assumption that experiential evidence, such as customer satisfaction, completely replaces stereotypical information, such as warmth and competence perceptions, in terms of driving trusting beliefs and intentions. This finding has important implications for trust development and provides an explanation as to why initiatives aimed at improving trust through offering experiential evidence of trustworthiness often fail (Mcknight $e t$ al., 1998). The addition of stereotypes to the literature on consumer loyalty development also provides a solid theoretical foundation for future studies concerning other types of stereotypes and underlying categories that could be diagnostic with regard to predicting consumers' trust, value and loyalty judgments.

Our results also have theoretical implications in relation to consumer stereotyping, as we are the first to suggest that consumers rely on multiple categories and resultant stereotypes at once. This extends the findings of prior studies, which examined only a single group or category underlying consumer stereotypes (Aaker et al., 2010; Kolbl et al., 2019; Smith et al., 2016). Moreover, we are the first to investigate the service industry, which is considered analogous to the product category (Loken, 2006), as the basis for consumer warmth and competence stereotypes. This extends previous studies that examined non-profit/profitoriented (Aaker et al., 2010), small/large (Yang and Aggarwal, 2019) and local/global service provider stereotypes (Davvetas and Halkias, 2019) as the drivers of consumers' beliefs, attitudes, and behaviors. An important avenue for future research would, therefore, be to identify the boundary conditions for the effects of different kinds of stereotypes. When are 
consumers more likely to rely on industry or product category stereotypes than on small/ large or local/global stereotypes?

Finally, our results show that both warmth and competence are important in relation to consumer-provider relationships. The prior literature offers mixed results, with some studies emphasizing the role of warmth (Güntürkün et al., 2020; Iglesias, 2004; Kolbl et al., 2019) and others the role of competence (Kirmani et al., 2017; Valta, 2013). We show that where trust, value and loyalty judgments are concerned, both warmth and competence have a considerable impact. This implies that focusing on narrow constructs such as consumers' brand identification or willingness to pay a price premium as the outcomes of warmth and competence stereotypes may result in an biased insight that favors one dimension over the other. When several constructs, such as trust and loyalty, are considered jointly, both stereotype dimensions appear to be important drivers of consumer judgments.

\section{Managerial implications}

Our results suggest that the development of consumer loyalty should be easier in certain service industries due to the more favorable warmth and competence stereotypes that consumers hold. This provides an explanation for the differences in the degree of consumer loyalty identified across various industries in previous studies (e.g. González-Benito and Martos-Partal, 2012). For example, our results indicate that the airline and hotel industries are stereotypically warmer than the insurance and telecommunications industries, while the insurance industry is stereotypically less competent than the hotel and airline industries. Thus, managers should take such industry stereotypes into account when setting goals concerning customer retention and loyalty, which will prove more difficult to achieve in certain industries (e.g. insurance).

The managerial literature proclaims the end of consumer loyalty (Demers, 2017) and considers cultural shifts as one of reason for its decline (Kusek, 2016). It also calls for the reinvention of customer service, since consumers are more likely to complain about poor service than to reward good service, which suggests there is no reason for service providers to excel in relation to consumer satisfaction (Dixon et al., 2010; Dixon et al., 2017). Stereotypes, as socially shared sets of beliefs (Kolbl et al., 2019; Kolbl et al., 2020), can capture this cultural change and so affect managers who seek to build loyalty by implementing differentiation and positioning strategies on the basis of consumer satisfaction. The effectiveness of such strategies could be hampered by consumers' industry stereotypes. As a result, managers from negatively stereotyped industries should adopt coopetition strategies designed to improve consumers' stereotypical perceptions of their industries, which should help to promote loyalty to all industry members (Bengtsson and Raza-Ullah, 2016). For instance, companies could engage in joint corporate social-responsibility initiatives, ensure fair supplychain practices or reach an industry-level employment agreement that guarantees a living wage to all employees in order to improve the industry's warmth stereotypes (Shea and Hawn, 2019). Alternatively, companies could introduce industry-wide quality and/or governance standards, which should improve the industry's competence stereotypes. There exists evidence to suggest that such industry-wide initiatives are less likely to be perceived as unauthentic, which means they are highly unlikely to backfire (Gilbert et al., 2011; Paine et al., 2005).

Service providers often use customer satisfaction scores as a proxy for customer ratings of frontline employees' work-related outcomes (Dixon et al., 2010). In this context, we point to the occupational stereotypes that affect consumer ratings of frontline employees. In fact, our findings challenge the standard practices of the service industry. Several customer care professions typically experience a high turnover rate due to the lack of challenging work and insufficient recognition (Dixon, 2018). Different professions are associated with different levels of warmth and competence (He et al., 2019; Imhoff et al., 2018), which influences 
JOSM 32,6

consumers' trusting beliefs about frontline employees. This has implications for frontline employee reward systems based on consumer satisfaction (Dixon, 2018). Such reward systems should take into account the differences in the assessment of frontline employees that result from occupational stereotypes. Moreover, activities designed to present and/or reorganize the work of different service occupations could lead to a higher assessment of occupational warmth and competence on the one hand and a lower staff turnover rate on the other.

\section{Limitations and future research}

This study is not without limitations that could serve as avenues for future research. First, we conceptualized two types of stereotypes, although other types of stereotypes might be relevant to evaluations of both frontline employees (e.g. age, gender and race) and company or management practices and policies (e.g. global/local, country of origin and for-profit/nonprofit service providers). It would be useful if future studies simultaneously examined the effects of additional stereotypes. As our research did not include the measurement of consumers' overall satisfaction, it is not possible to state how the results would change if we used a measure of overall satisfaction, rather than of encounter-specific satisfaction, in our model. Nevertheless, we believe that our decision to employ encounter-specific satisfaction instead of cumulative satisfaction does not diminish our ability to address our main research question (i.e. why satisfaction levels have been increasing, while trust and loyalty levels have been decreasing). In fact, there is substantial evidence to suggest that consumers' cumulative satisfaction is largely determined by their satisfaction with the most recent service encounter, that is, encounter-specific satisfaction (Keiningham et al., 2014; Pizzi et al., 2015).

The second limitation is related to the cross-sectional study design, which can provide only tentative support for the hypothesized causal effects (Bagozzi and Yi, 2012). Thus, future studies should consider experimental designs, which would allow for the group membership of both frontline employees and companies to be varied exogenously. Finally, we examined the relationships within a single culture. As there is some evidence to suggest that both satisfaction-trust relationships (Fatima et al., 2018) and stereotyping (Fiske, 2017) function differently across cultures, this offers a number of avenues for future research.

\section{References}

Aaker, J.L., Vohs, K. and Mogilner, C. (2010), "Nonprofits are seen as warm and for-profits as competent: firm stereotypes matter", Journal of Consumer Research, Vol. 37, pp. 224-237.

Abbey, J.D. and Meloy, M.G. (2017), "Attention by design: using attention checks to detect inattentive respondents and improve data quality", Journal of Operations Management, Vols 53-56, pp. 63-70.

Agustin, C. and Singh, J. (2005), "Curvilinear effects of consumer loyalty determinants in relational exchanges", Journal of Marketing Research, Vol. 42, pp. 96-108.

Alexandrov, A., Lilly, B. and Babakus, E. (2013), "The effects of social- and self-motives on the intentions to share positive and negative word of mouth", Journal of the Academy of Marketing Science, Vol. 41, pp. 531-546.

American Customer Satisfaction Index (ACSI) (2019), "U.S. Overall customer satisfaction", available at: https://www.theacsi.org/national-economic-indicator/us-overall-customer-satisfaction (accessed 27 June 2020).

Bagozzi, R.P. (2011), "Measurement and meaning in information systems and organizational research: methodological and philosophical foundations", MIS Quarterly, Vol. 35, pp. 261-292.

Bagozzi, R.P. and Yi, Y. (2012), "Specification, evaluation, and interpretation of structural equation models", Journal of the Academy of Marketing Science, Vol. 40, pp. 8-34. 
Bajde, D. (2019), “Branding an industry?”, Journal of Brand Management, Vol. 26, pp. 497-504.

Consumers'

Batra, R., Lenk, P. and Wedel, M. (2010), "Brand extension strategy planning: empirical estimation of brand-category personality fit and atypicality", Journal of Marketing Research, Vol. 47, pp. 335-347.

Bengtsson, M. and Raza-Ullah, T. (2016), “A systematic review of research on coopetition: toward a multilevel understanding”, Industrial Marketing Management, Vol. 57, pp. 23-39.

Bolton, R.N. and Drew, J.H. (1991a), "A longitudinal analysis of the impact of service changes on customer attitudes", Journal of Marketing, Vol. 55, pp. 1-9.

Bolton, R.N. and Drew, J.H. (1991b), “A multistage model of customers' assessments of service quality and value", Journal of Consumer Research, Vol. 17, pp. 375-384.

Brocato, E.D., Baker, J. and Voorhees, C.M. (2015), "Creating consumer attachment to retail service firms through sense of place", Journal of the Academy of Marketing Science, Vol. 43, pp. 200-220.

Chai, J.C.Y., Malhotra, N.K. and Alpert, F. (2015), "A two-dimensional model of trust-value-loyalty in service relationships", Journal of Retailing and Consumer Services, Vol. 26, pp. 23-31.

Cuddy, A.J.C., Fiske, S.T. and Glick, P. (2007), "The BIAS map: behaviors from intergroup affect and stereotypes", Journal of Personality and Social Psychology, Vol. 92, pp. 631-648.

Davies, G. and Chun, R. (2012), "Employee as symbol: stereotypical age effects on corporate brand associations”, European Journal of Marketing, Vol. 46, pp. 663-683.

Davvetas, V. and Halkias, G. (2019), "Global and local brand stereotypes: formation, content transfer, and impact", International Marketing Review, Vol. 36, pp. 675-701.

Dawes, J., Meyer-Waarden, L. and Driesener, C. (2015), "Has brand loyalty declined? A longitudinal analysis of repeat purchase behavior in the UK and the USA", Journal of Business Research, Vol. 68, pp. 425-432.

Demers, J. (2017), "Is the concept of brand loyalty dying?", Forbes, available at: https://www.forbes. com/sites/jaysondemers/2017/06/09/is-the-concept-of-brand-loyalty-dying/\#3671aa4a5b52 (accessed 3 May 2019).

Dick, A.S. and Basu, K. (1994), "Customer loyalty: toward an integrated conceptual framework", Journal of the Academy of Marketing Science, Vol. 22, pp. 99-113.

Dixon, M. (2018), "Reinventing customer service", Harvard Business Review, Vol. 96, p. 82.

Dixon, M., Freeman, K. and Toman, N. (2010), "STOP trying to delight your customers", Harvard Business Review, Vol. 88, pp. 116-122.

Dixon, M., Ponomareff, L., Turner, S. and Delisi, R. (2017), "Kick-ass customer service", Harvard Business Review, Vol. 95, pp. 110-117.

Edeling, A. and Fischer, M. (2016), "Marketing's impact on firm value: generalizations from a metaanalysis", Journal of Marketing Research, Vol. 53, pp. 515-534.

Edelman (2020), "Edelman trust barometer 2020", available at: https://www.edelman.com/trust/2020trust-barometer (accessed 13 May 2020).

El-Manstrly, D. (2016), "Enhancing customer loyalty: critical switching cost factors", Journal of Service Management, Vol. 27.

Evanschitzky, H., Ramaseshan, B., Brady, M.K., Rabbanee, F.K., Brock, C. and Pokorska-Zare, J. (2020), "Consumer relationship fading", Psychology and Marketing, Vol. 37, pp. 815-836.

Fatima, J.K., Mascio, R.D. and Johns, R. (2018), "Impact of relational benefits on trust in the Asian context: alternative model testing with satisfaction as a mediator and relationship age as a moderator", Psychology and Marketing, Vol. 35, pp. 443-453.

Fiske, S.T. (2017), "Prejudices in cultural contexts: shared stereotypes (gender, age) versus variable stereotypes (race, ethnicity, religion)", Perspectives on Psychological Science, Vol. 12, pp. 791-799.

Fiske, S.T. (2018), "Stereotype content: warmth and competence endure", Current Directions in Psychological Science, Vol. 27, pp. 67-73. 
JOSM 32,6

Fiske, S.T., Cuddy, A.J.C., Glick, P. and Xu, J. (2002), "A model of (often mixed) stereotype content: competence and warmth respectively follow from perceived status and competition", Journal of Personality and Social Psychology, Vol. 82, pp. 878-902.

Foddy, M., Platow, M.J. and Yamagishi, T. (2009), "Group-based trust in strangers: the role of stereotypes and expectations", Psychological Science, Vol. 20, pp. 419-422.

Folkes, V.S. and Patrick, V.M. (2003), "The positivity effect in perceptions of services: seen one, seen them all?", Journal of Consumer Research, Vol. 30, pp. 125-137.

Forbes, S. and Avis, M. (2020), "Construct creation from research questions”, European Journal of Marketing, Vol. 54, pp. 1817-1838.

Fornell, C., Johnson, M.D., Anderson, E.W., Cha, J. and Bryant, B.E. (1996), "The American customer satisfaction index: nature, purpose, and findings", Journal of Marketing, Vol. 60, pp. 7-18.

Fornell, C., Morgeson, F.V. and Hult, G.T.M. (2016), "An abnormally abnormal intangible: stock returns on customer satisfaction”, Journal of Marketing, Vol. 80, pp. 122-125.

Fournier, S. and Alvarez, C. (2012), "Brands as relationship partners: warmth, competence, and inbetween”, Journal of Consumer Psychology, Vol. 22, pp. 177-185.

Gilbert, D.U., Rasche, A. and Waddock, S. (2011), "Accountability in a global economy: the emergence of international accountability standards", Business Ethics Quarterly, Vol. 21 No. 1, pp. 23-44.

Gill, T. (2017), "Ethnic stereotyping in service provision", Journal of Service Theory and Practice, Vol. 27, pp. 520-546.

González-Benito, Ó. and Martos-Partal, M. (2012), "Role of retailer positioning and product category on the relationship between store brand consumption and store loyalty", Journal of Retailing, Vol. 88, pp. 236-249.

Güntürkün, P., Haumann, T. and Mikolon, S. (2020), "Disentangling the differential roles of warmth and competence judgments in customer-service provider relationships", Journal of Service Research, Vol. 23, pp. 476-503.

Gunia, B.C. and Levine, E.E. (2019), "Deception as competence: the effect of occupational stereotypes on the perception and proliferation of deception", Organizational Behavior and Human Decision Processes, Vol. 152, pp. 122-137.

Halkias, G., Davvetas, V. and Diamantopoulos, A. (2016), "The interplay between country stereotypes and perceived brand globalness/localness as drivers of brand preference", Journal of Business Research, Vol. 69, pp. 3621-3628.

Hareli, S., David, S. and Hess, U. (2013), "Competent and warm but unemotional: the influence of occupational stereotypes on the attribution of emotions", Journal of Nonverbal Behavior, Vol. 37, pp. 307-317.

Hayes, A.F., Montoya, A.K. and Rockwood, N.J. (2017), "The analysis of mechanisms and their contingencies: PROCESS versus structural equation modeling", Australasian Marketing Journal (AMJ), Vol. 25, pp. 76-81.

He, J.C., Kang, S.K., Tse, K. and Toh, S.M. (2019), "Stereotypes at work: occupational stereotypes predict race and gender segregation in the workforce", Journal of Vocational Behavior, Vol. 115, p. 103318.

Hess, A.C. and Melnyk, V. (2016), "Pink or blue? The impact of gender cues on brand perceptions", European Journal of Marketing, Vol. 50, pp. 1550-1574.

Huetten, A.S.J., Antons, D., Breidbach, C.F., Piening, E.P. and Salge, T.O. (2019), "The impact of occupational stereotypes in human-centered service systems", Journal of Service Management, Vol. 30, pp. 132-155.

Iacobucci, D., Saldanha, N. and Deng, X.Y. (2007), "A meditation on mediation: evidence that structural equations models perform better than regressions", Journal of Consumer Psychology, Vol. 17, pp. 139-153. 
Iglesias, V. (2004), "Preconceptions about service: how much do they influence quality evaluations?", Journal of Service Research, Vol. 7, pp. 90-103.

Imhoff, R., Koch, A. and Flade, F. (2018), "(Pre)occupations: a data-driven model of jobs and its consequences for categorization and evaluation", Journal of Experimental Social Psychology, Vol. 77, pp. 76-88.

Ivens, B.S., Leischnig, A., Muller, B. and Valta, K. (2015), "On the role of brand stereotypes in shaping consumer response toward brands: an empirical examination of direct and mediating effects of warmth and competence", Psychology and Marketing, Vol. 32, p. 808.

Consumers' trust, value and loyalty judgments

Japutra, A., Molinillo, S. and Wang, S. (2018), "Aesthetic or self-expressiveness? Linking brand logo benefits, brand stereotypes and relationship quality", Journal of Retailing and Consumer Services, Vol. 44, pp. 191-200.

Karpen, I.O., Bove, L.L., Lukas, B.A. and Zyphur, M.J. (2015), "Service-dominant orientation: measurement and impact on performance outcomes", Journal of Retailing, Vol. 91, pp. 89-108.

Keiningham, T.L., Aksoy, L., Malthouse, C.E., Lariviere, B. and Buoye, A. (2014), "The cumulative effect of satisfaction with discrete transactions on share of wallet", Journal of Service Management, Vol. 25, pp. 310-333.

Khamitov, M., Wang, X. and Thomson, M. (2019), "How well do consumer-brand relationships drive customer brand loyalty? Generalizations from a meta-analysis of brand relationship elasticities", Journal of Consumer Research, Vol. 46, pp. 435-459.

Kirmani, A., Lantzy, S., Hamilton, R.W. and Thompson, D.V. (2017), "Doing well versus doing good: the differential effect of underdog positioning on moral and competent service providers", Journal of Marketing, Vol. 81, pp. 103-117.

Kolbl, Ž., Arslanagic-kalajdzic, M. and Diamantopoulos, A. (2019), "Stereotyping global brands: is warmth more important than competence?", Journal of Business Research, Vol. 104, pp. 614-621.

Kolbl, Ž., Diamantopoulos, A., Arslanagic-Kalajdzic, M. and Zabkar, V. (2020), "Do brand warmth and brand competence add value to consumers? A stereotyping perspective", Journal of Business Research, Vol. 118, pp. 346-362.

Kumar, V. (2018), “A theory of customer valuation: concepts, metrics, strategy, and implementation”, Journal of Marketing, Vol. 82, pp. 1-19.

Kusek, K. (2016), "The death of brand loyalty: cultural shifts mean it's gone forever", Forbes, available at: https://www.forbes.com/sites/kathleenkusek/2016/07/25/the-death-of-brand-loyalty-culturalshifts-mean-its-gone-forever/amp/ (accessed 16 June 2019).

Li, F., Kashyap, R., Zhou, N. and Yang, Z. (2008), "Brand trust as a second-order factor. An alternative measurement model”, International Journal of Market Research, Vol. 50, pp. 817-839.

Loken, B. (2006), "Consumer psychology: categorization, inferences, affect, and persuasion”, Annual Review of Psychology, Vol. 57, pp. 453-485.

Lynch, J.G., Bradlow, E.T., Huber, J.C. and Lehmann, D.R. (2015), "Reflections on the replication corner: in praise of conceptual replications", International Journal of Research in Marketing, Vol. 32, pp. 333-342.

Macinnis, D.J. (2011), “A framework for conceptual contributions in marketing”, Journal of Marketing, Vol. 75, pp. 136-154.

Macrae, C.N., Milne, A.B. and Bodenhausen, G.V. (1994), "Stereotypes as energy-saving devices: a peek inside the cognitive toolbox", Journal of Personality and Social Psychology, Vol. 66, pp. 37-47.

Madera, J.M., Taylor, D.C. and Barber, N.A. (2019), "Customer service evaluations of employees with disabilities: the roles of perceived competence and service failure", Cornell Hospitality Quarterly, Vol. 61, pp. 5-18.

Marinova, D. and Singh, J. (2014), "Consumer decision to upgrade or downgrade a service membership", Journal of the Academy of Marketing Science, Vol. 42, pp. 596-618.

Martineau, P. (1958), "Sharper focus for the corporate image", Harvard Business Review, Vol. 36, p. 49. 
JOSM 32,6
Matta, S. and Folkes, V.S. (2005), "Inferences about the brand from counterstereotypical service providers", Journal of Consumer Research, Vol. 32, pp. 196-206.

Mayer, R.C., Davis, J.H. and Schoorman, F.D. (1995), “An integrative model of organizational trust”, Academy of Management Review, Vol. 20, pp. 709-734.

Mcknight, D.H., Cummings, L.L. and Chervany, N.L. (1998), "Initial trust formation in new organizational relationships", Academy of Management Review, Vol. 23, pp. 473-490.

Mikolon, S., Kreiner, G.E. and Wieseke, J. (2016), "Seeing you seeing me: stereotypes and the stigma magnification effect", Journal of Applied Psychology, Vol. 101, pp. 639-656.

Molinillo, S., Gómez-Ortiz, B., Pérez-Aranda, J. and Navarro-García, A. (2017), "Building customer loyalty: the effect of experiential state, the value of shopping, and trust and perceived value of service on online clothes shopping”, Clothing and Textiles Research Journal, Vol. 35, pp. 156-171.

Moorman, C., Deshpandé, R. and Zaltman, G. (1993), "Factors affecting trust in market research relationships", Journal of Marketing, Vol. 57, pp. 81-101.

Morgan, R.M. and Hunt, S.D. (1994), "The commitment-trust theory of relationship marketing”, Journal of Marketing, Vol. 58, pp. 20-38.

Nightingale, J. (1978), "On the definition of 'Industry' and 'Market”, The Journal of Industrial Economics, Vol. 27, pp. 31-40.

Nijssen, E. and Van Herk, H. (2009), "Conjoining international marketing and relationship marketing: exploring consumers' cross-border service relationships”, Journal of International Marketing, Vol. 17, pp. 91-115.

Nijssen, E., Singh, J., Sirdeshmukh, D. and Holzmüeller, H. (2003), "Investigating industry context effects in consumer-firm relationships: preliminary results from a dispositional approach", Journal of the Academy of Marketing Science, Vol. 31, pp. 46-60.

Oliver, R.L. (1999), “Whence consumer loyalty?”, Journal of Marketing, Vol. 63, pp. 33-44.

Paine, L., Deshpandé, R., Margolis, J.D. and Bettcher, K.E. (2005), "Up to code: does your company's conduct meet world-class standards?", Harvard Business Review, Vol. 83 No. 12, pp. 122-133.

Palmatier, R.W., Dant, R.P., Grewal, D. and Evans, K.R. (2006), "Factors influencing the effectiveness of relationship marketing: a meta-analysis", Journal of Marketing, Vol. 70, pp. 136-153.

Peer, E., Brandimarte, L., Samat, S. and Acquisti, A. (2017), "Beyond the Turk: alternative platforms for crowdsourcing behavioral research”, Journal of Experimental Social Psychology, Vol. 70, pp. 153-163.

Petersen, J.A., Kumar, V., Polo, Y. and Sese, F.J. (2018), "Unlocking the power of marketing: understanding the links between customer mindset metrics, behavior, and profitability", Journal of the Academy of Marketing Science, Vol. 46, pp. 813-836.

Pinar, M., Wilder, C., Shaltoni, A.M. and Stück, J.M. (2017), "Effects of gender, occupational stereotyping, and culture on perceived service quality in anglo-saxon and middle eastern cultures", Services Marketing Quarterly, Vol. 38, pp. 57-73.

Pizzi, G., Marzocchi, G.L., Orsingher, C. and Zammit, A. (2015), "The temporal construal of customer satisfaction", Journal of Service Research, Vol. 18, pp. 484-497.

Podsakoff, P.M., Mackenzie, S.B. and Podsakoff, N.P. (2012), "Sources of method bias in social science research and recommendations on how to control it", Annual Review of Psychology, Vol. 63, pp. 539-569.

Rajavi, K., Kushwaha, T. and Steenkamp, J.-B.E.M. (2019), "In brands we trust? A multicategory, multicountry investigation of sensitivity of consumers' trust in brands to marketing-mix activities", Journal of Consumer Research, Vol. 46, pp. 651-670.

Rosch, E.H. (1973), "Natural categories", Cognitive Psychology, Vol. 4, pp. 328-350.

Rosengren, S. and Dahlén, M. (2015), "Exploring advertising equity: how a brand's past advertising may affect consumer willingness to approach its future ads", Journal of Advertising, Vol. 44, pp. 1-13. 
Schneider, D.J. (2005), The Psychology of Stereotyping, Guilford, NY; London.

Consumers'

Shea, C.T. and Hawn, O. (2019), "Microfoundations of corporate social responsibility and trust, value and irresponsibility", Academy of Management Journal, Vol. 62, pp. 1609-1642.

Singh, J. and Sirdeshmukh, D. (2000), "Agency and trust mechanisms in consumer satisfaction and loyalty judgments", Journal of the Academy of Marketing Science, Vol. 28, pp. 150-167.

Singh, J., Lentz, P. and Nijssen, E. (2011), "First- and second-order effects of consumers' institutional logics on firm-consumer relationships: a cross-market comparative analysis", Journal of International Business Studies, Vol. 42, pp. 307-333.

Sirdeshmukh, D., Singh, J. and Sabol, B. (2002), "Consumer trust, value, and loyalty in relational exchanges", Journal of Marketing, Vol. 66, pp. 15-37.

Smith, N.A., Martinez, L.R. and Sabat, I.E. (2016), "Weight and gender in service jobs: the importance of warmth in predicting customer satisfaction", Cornell Hospitality Quarterly, Vol. 57, pp. 314-328.

Timming, A., Baumann, C. and Gollan, P. (2020), "Consumer preferences for gender typicality in frontline services staff in the United States vis-à-vis South Korea: an experimental approach", European Journal of Marketing, Vol. 54 No. 8, pp. 1839-1864.

Tombs, A. and Rao Hill, S. (2014), "The effect of service employees' accent on customer reactions", European Journal of Marketing, Vol. 48, pp. 2051-2070.

Tucker, W.T. (1961), "How much of the corporate image is stereotype?", Journal of Marketing, Vol. 25, pp. 61-65.

Valta, K.S. (2013), "Do relational norms matter in consumer-brand relationships?", Journal of Business Research, Vol. 66, pp. 98-104.

Vieira, V.A. (2013), “Antecedents and consequences of perceived value: a meta-analytical perspective”, Journal of Customer Behaviour, Vol. 12, pp. 111-133.

Voorhees, C.M., Calantone, R., Brady, M.K. and Ramirez, E. (2016), "Discriminant validity testing in marketing: an analysis, causes for concern, and proposed remedies", Journal of the Academy of Marketing Science, Vol. 44, pp. 119-134.

Watson, G.F., Beck, J.T., Henderson, C.M. and Palmatier, R.W. (2015), "Building, measuring, and profiting from customer loyalty", Journal of the Academy of Marketing Science, Vol. 43, pp. $790-825$.

Williams, M. (2001), "Whom we trust: group membership as an affective context for trust development”, Academy of Management Review, Vol. 26, pp. 377-396.

Wu, L., Han, R. and Mattila, A.S. (2016), "A double whammy effect of ethnicity and gender on consumer responses to management level service failures", Journal of Service Management, Vol. 27, pp. 339-359.

Yang, L.W. and Aggarwal, P. (2019), "No small matter: how company size affects consumer expectations and evaluations", Journal of Consumer Research, Vol. 45, pp. 1369-1384.

Zhao, X., Lynch, J. and Chen, Q. (2010), "Reconsidering Baron and Kenny: myths and truths about mediation analysis", Journal of Consumer Research, Vol. 37, pp. 197-206.

\section{Corresponding author}

Petar Gidaković can be contacted at: petar.gidakovic@ef.uni-lj.si

For instructions on how to order reprints of this article, please visit our website:

www.emeraldgrouppublishing.com/licensing/reprints.htm

Or contact us for further details: permissions@emeraldinsight.com 